\title{
Intensification of Northern Hemisphere subtropical highs in a warming climate
}

\author{
Wenhong $\mathrm{Li}^{1 \star}$, Laifang $\mathrm{Li}^{1}$, Mingfang Ting ${ }^{2}$ and Yimin Liu ${ }^{3}$
}

Semi-permanent high-pressure systems over the subtropical oceans, known as subtropical highs, influence atmospheric circulation, as well as global climate. For instance, subtropical highs largely determine the location of the world's subtropical deserts, the zones of Mediterranean climate and the tracks of tropical cyclones. The intensity of two such high-pressure systems, present over the Northern Hemisphere oceans during the summer, has changed in recent years. However, whether such changes are related to climate warming remains unclear. Here, we use climate model simulations from the Intergovernmental Panel on Climate Change Fourth Assessment Report, reanalysis data from the 40-year European Centre for Medium-Range Weather Forecasts, and an idealized general circulation model, to assess future changes in the intensity of summertime subtropical highs over the Northern Hemisphere oceans. The simulations suggest that these summertime highs will intensify in the twenty-first century as a result of an increase in atmospheric greenhouse-gas concentrations. We further show that the intensification of subtropical highs is predominantly caused by an increase in thermal contrast between the land and ocean. We suggest that summertime near-surface subtropical highs could play an increasingly important role in regional climate and hydrological extremes in the future.

$\mathrm{N}$ ear-surface subtropical highs are semi-permanent features over oceans that are fundamental elements of atmospheric circulation. These subtropical highs, also known as subtropical anticyclones, connect the tropical trade wind regime with the midlatitude westerly belt in the near-surface flow, playing a major role in the formation of the world's subtropical deserts and the zones of Mediterranean climate ${ }^{1-3}$. During boreal summer, two subtropical highs are observed over Northern Hemisphere oceans (Fig. 1), namely the North Atlantic Subtropical High (also known as the Bermuda High ${ }^{4}$ ), and the North Pacific Subtropical High $^{5}$. These summer near-surface subtropical anticyclones have been found to strongly influence moisture transport and thus affect regional precipitation ${ }^{6-8}$, monsoon circulation ${ }^{9,10}$, tropical cyclone tracks ${ }^{11-13}$, and marine stratus clouds and their associated radiation budget ${ }^{14,15}$.

In recent years, the North Atlantic Subtropical High has been found to intensify, causing a westward movement of its western ridge in summer ${ }^{7}$. Over the western North Pacific, the western ridge of the North Pacific Subtropical High has also been observed to move westward significantly in summer ${ }^{5,16}$. The impacts of the subtropical highs on the East Asian summer monsoon, summer rainfall in the southeastern and central US are enhanced as the systems move closer to the continents ${ }^{7,16-18}$. Whether the summer subtropical anticyclones over the Northern Hemisphere oceans intensify in general, or the intensification is only limited to the North Atlantic region, however, has not been studied systematically. If the intensification has indeed been true for the Northern Hemisphere as a whole, what physical processes are responsible? Over the North Atlantic, strengthening of the North Atlantic Subtropical High seems to be related to global warming ${ }^{7}$, similar to the results of ref. 19 . Understanding the general features and causes of the changes

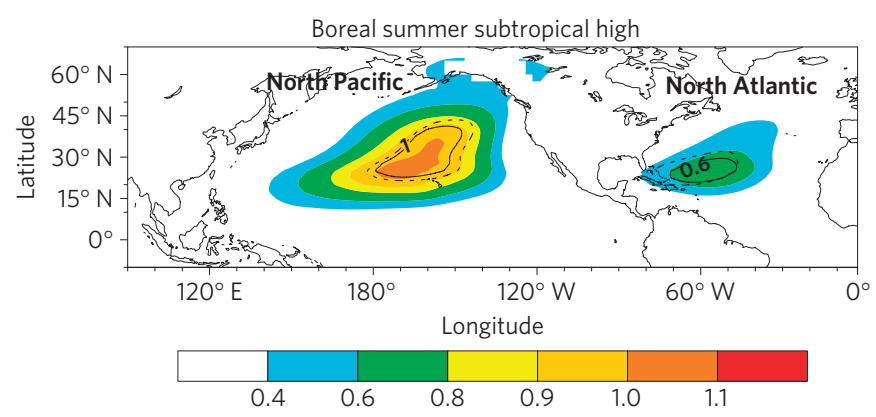

Figure 1 | Climatology of summertime subtropical highs in the Northern Hemisphere. The $925 \mathrm{hPa}$ zonally asymmetric component of the stream function (unit: $10^{7} \mathrm{~m}^{2} \mathrm{~s}^{-2}$ ) of the ERA-40 reanalysis (shaded) and the CMIP3 multi-model ensemble mean (contour). Local maxima in the stream function field for the North Pacific Subtropical High $\left(1 \times 10^{7} \mathrm{~m}^{2} \mathrm{~s}^{-2}\right)$ and the North Atlantic Subtropical High $\left(0.6 \times 10^{7} \mathrm{~m}^{2} \mathrm{~s}^{-2}\right)$ are plotted, respectively, in the twentieth (1950-1999, solid) and the twenty-first (2050-2099, dashed) centuries.

in subtropical anticyclones would allow for better projections of regional weather and climate; for example, the summer rainfall variability and extremes over the central and southeastern US (refs 7,20-22), East Asian summer monsoons ${ }^{16,17}$ and tropical cyclone track changes ${ }^{11-13}$.

Intensification of Northern Hemisphere subtropical highs This study addresses the intensity change of the two summertime near-surface subtropical anticyclones over the North Pacific and North Atlantic in a warming climate using the $925 \mathrm{hPa}$ stream function in the 40-year European Centre for Medium-Range 


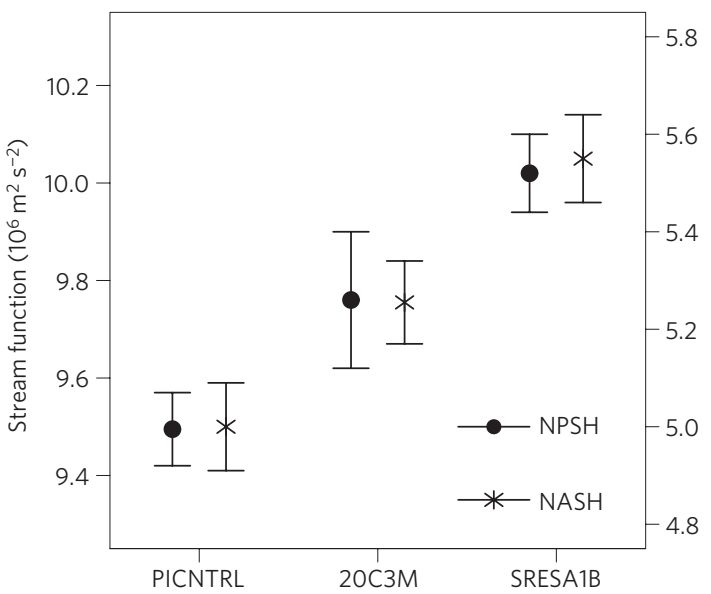

Figure 2 | Simulated domain-averaged summertime subtropical highs' intensity. The $925 \mathrm{hPa}$ zonally asymmetric component of the stream function (unit: $10^{6} \mathrm{~m}^{2} \mathrm{~s}^{-2}$ ) for the North Pacific Subtropical High (NPSH; left $y$ axis) and the North Atlantic Subtropical High (NASH; right $y$ axis) using 50-year pre-industry (PICNTRL), twentieth-century (20C3M, 1950-1999), and twenty-first-century (SRESA1B, 2050-2099) simulations. Mean (dot for the North Pacific Subtropical High and asterisk for the North Atlantic Subtropical High) and 95\% confidence interval of the subtropical highs' intensity among all the CMIP3 models, based on $t$-tests, are shown. The domains of the North Pacific Subtropical High and North Atlantic Subtropical High are $20^{\circ}-40^{\circ} \mathrm{N}, 180^{\circ}-220^{\circ} \mathrm{E}$ and $20^{\circ}-35^{\circ} \mathrm{N}$, $290^{\circ}-320^{\circ} \mathrm{E}$, respectively.

Weather Forecasts (ECMWF) Re-Analysis (ERA-40) data set from 1958 to 2002 (ref. 23), and all climate models participating in the Intergovernmental Panel on Climate Change Fourth Assessment Report (IPCC AR4), also known as the Coupled Model Intercomparison Project phase 3 (CMIP3; ref. 24). Figure 1 shows the CMIP3 models' simulation (contours) of the summertime climatological stream function for the North Pacific Subtropical High and North Atlantic Subtropical High, respectively, along with the ERA-40 reanalysis (colour shading) with the zonal mean removed. Near-surface anticyclonic circulation over the North Pacific is generally stronger than the circulation over the North Atlantic (Fig. 1). The shapes of the two subtropical anticyclonic systems in the twentieth century (1950-1999) are reasonably captured by the CMIP3 models (Fig. 1); however, the intensity of the North Pacific Subtropical High (North Atlantic Subtropical High) is stronger (weaker) in the CMIP3 models when compared with that from the ERA-40 reanalysis (Fig. 1). In the twentyfirst century (2050-2099), CMIP3 models project expansion and centre intensification for both subtropical highs in boreal summers (Fig. 1); the North Pacific Subtropical High expands uniformly in all directions, whereas the North Atlantic Subtropical High expands more westward. The same results are seen from the domain-averaged intensity ${ }^{4}$ changes of the two anticyclonic systems in the Northern Hemisphere using the CMIP3 models' output (Fig. 2, discussed below).

In the present climate, the ERA-40 reanalysis suggested a consistent strengthening for both summertime subtropical highs: the average stream function increases at an average rate of about $10^{4} \mathrm{~m}^{2} \mathrm{~s}^{-2}$ per decade and $1.7 \times 10^{5} \mathrm{~m}^{2} \mathrm{~s}^{-2}$ per decade for the North Pacific Subtropical High and the North Atlantic Subtropical High, respectively, during the period 1958-2002. The Mann-Kendall test shows that the trend of North Atlantic Subtropical High intensification is significant, at the $95 \%$ confidence level.

Are these changes caused mainly by natural climate variability or by anthropogenic forcing? To answer this question, we compare the intensity changes of the two Northern Hemisphere subtropical

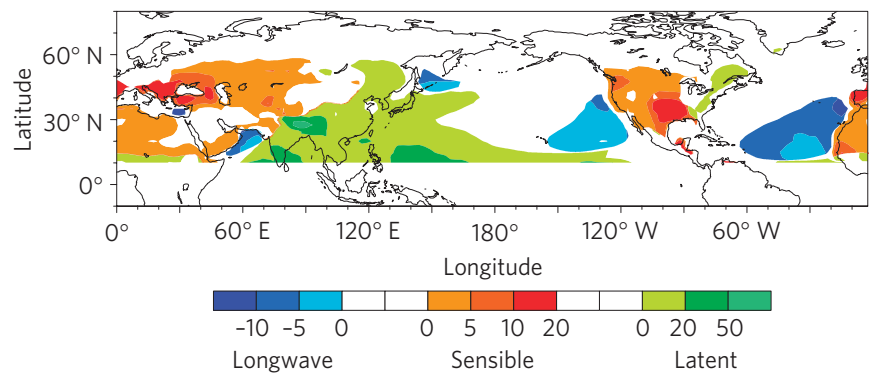

Figure 3 | Changes in the dominant heating component between the twenty-first- and twentieth-century run. Blue, red and green colours denote long-wave radiative cooling, sensible heating and condensational heating, respectively, obtained from the CMIP3 multi-model ensemble mean. (Unit: $\mathrm{W} \mathrm{m}^{2}$.)

highs using the ensemble simulations of all CMIP3 models participating in the IPCC AR4, driven by three scenarios ${ }^{25}$ : a fixed atmospheric concentration of $\mathrm{CO}_{2}$ at $280-290 \mathrm{ppm}$ (the pre-industrial scenario); the observed long-lived greenhouse gases (GHGs), solar radiation and volcanic aerosols for the twentieth century (the twentieth-century anthropogenic external forcing scenario); and an increase of the atmospheric concentration of $\mathrm{CO}_{2}$ globally to $720 \mathrm{ppm}$ by year 2100 (the twenty-first-century A1B scenario). Figure 2 illustrates the multi-model ensemble mean intensity of the North Pacific Subtropical High and the North Atlantic Subtropical High produced by 50 -year pre-industrial, twentieth-century (1950-1999) and twenty-first-century (20502099) simulations. The multi-model ensemble domain-averaged intensity of the North Pacific Subtropical High is about $9.50 \times$ $10^{6} \mathrm{~m}^{2} \mathrm{~s}^{-2}$ in the pre-industrial simulation, and the CMIP3 models suggest that the North Pacific Subtropical High intensity is within $9.42 \times 10^{6} \mathrm{~m}^{2} \mathrm{~s}^{-2}$ and $9.57 \times 10^{6} \mathrm{~m}^{2} \mathrm{~s}^{-2}$ (95\% confidence interval). The twentieth-century simulation, however, indicates a clear enhancement of anticyclonic circulation for the North Pacific Subtropical High relative to the pre-industrial simulation although its multi-model ensemble mean intensity is about $2 \%$ stronger than that of the ERA-40 reanalysis $\left(9.61 \times 10^{6} \mathrm{~m}^{2} \mathrm{~s}^{-2}\right)$. Specifically, the multi-model ensemble mean intensity of the North Pacific Subtropical High in the twentieth century is about $9.76 \times 10^{6} \mathrm{~m}^{2} \mathrm{~s}^{-2}$, with a $95 \%$ confidence interval of $9.62 \times$ $10^{6} \mathrm{~m}^{2} \mathrm{~s}^{-2}$ to $9.90 \times 10^{6} \mathrm{~m}^{2} \mathrm{~s}^{-2}$. The difference between the North Pacific Subtropical High intensity in the twentieth century and the pre-industrial simulation is at a $99.99 \%$ confidence level ( $\chi^{2}$ test). Similar results are also found for the North Atlantic Subtropical High: the domain-averaged North Atlantic Subtropical High intensity is enhanced from $5.00 \times 10^{6} \mathrm{~m}^{2} \mathrm{~s}^{-2}$ in the preindustrial simulation to $5.28 \times 10^{6} \mathrm{~m}^{2} \mathrm{~s}^{-2}$ in the twentieth-century simulation (1950-1999), although the multi-model ensemble mean North Atlantic Subtropical High intensity is about $16 \%$ weaker in the CMIP3 models relative to that of the ERA-40 reanalysis. The summertime subtropical highs will further intensify in the twenty-first century (2050-2099) as shown by the changes of the multi-model ensemble mean stream function of the two Northern Hemisphere subtropical highs in Figs 1 and 2. In addition to the enhancement of the anticyclonic circulation fields for the North Pacific Subtropical High $\left(10.1 \times 10^{6} \mathrm{~m}^{2} \mathrm{~s}^{-2}\right)$ and North Atlantic Subtropical High $\left(5.58 \times 10^{6} \mathrm{~m}^{2} \mathrm{~s}^{-2}\right)$ in the twenty-first century with a GHG increase (Fig. 2), the areas of the subtropical highs expand. The central regions of the anticyclones expand by about $80 \%$ and $100 \%$ for the North Pacific Subtropical High and the North Atlantic Subtropical High, respectively, from the twentieth to the twenty-first century (Fig. 1). Overall, the CMIP3 model simulations demonstrate a general intensification of nearsurface summertime subtropical anticyclones in the Northern 
a

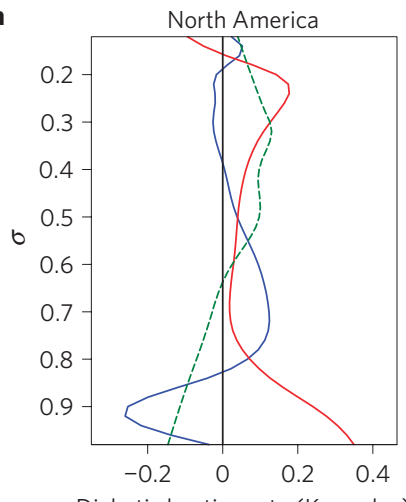

Diabetic heating rate ( $\mathrm{K}$ per day) b

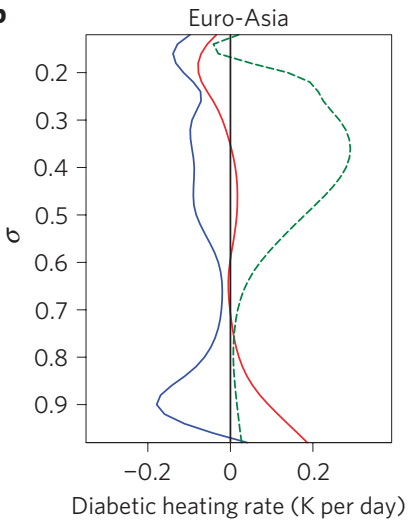

- Ocean (east)

Land (west)

--- Land (east)

Figure 4 | Changes in the multi-model ensemble mean vertical profile of total diabatic heatings. a,b, Red (blue) solid lines are the heating changes between the 2050-2099 and 1950-1999 periods over western continents (eastern oceans) where sensible heating (long-wave radiative cooling) dominates; green dashed lines are the profiles over eastern continents where condensation heating dominates, in the North America (a) and Euro-Asia (b) regions as in ref. 31. The $y$ axis is the $\sigma$-coordinate. Definitions of the western continents, eastern oceans and eastern continents are given in the Supplementary Information.

Hemisphere as a result of increases in GHG concentrations in the atmosphere.

\section{What causes the subtropical highs' strengthening?}

The existence of subtropical anticyclones has been historically linked to the descending branch of the Hadley cell in the subtropics ${ }^{26}$. However, subtropical anticyclones over oceans tend to be stronger in summer when the Hadley cell is weaker ${ }^{27,28}$. Multiple dynamic mechanisms represented by different regional diabatic heatings have been proposed in attempts to explain this contradiction ${ }^{1,29,30}$. In the summer subtropics, the dominant components of diabatic heating are: long-wave radiative cooling over the eastern oceans; and sensible and condensational heating over the western and eastern continents, respectively ${ }^{31}$, that is, heat sources over lands and heat sinks over oceans. Corresponding to such heating patterns, the atmospheric circulation in the subtropics is organized in the form of anticyclonic (cyclonic) circulation over oceans and cyclonic (anticyclonic) circulation over continents in the lower (upper) troposphere ${ }^{32,33}$. Studies found that the land surface sensible heating over the western continents, together with condensational heating over the eastern continents and radiative cooling over the oceans, brings the subtropical anticyclones closer to the observed strength in the lower troposphere ${ }^{31,34,35}$. Hereafter, we will analyse heating changes for the summertime subtropical anticyclones in the Northern Hemisphere from the twentieth century to the twenty-first century, when GHGs increase markedly.

CMIP3 multi-model ensemble results suggest that the climatological pattern and magnitude of the modelled total column diabatic heating, as well as dominant heating components, agree reasonably well with observations of the climate mean states in the twentieth century (Supplementary Information). In a warming climate, what are the changes of the total column dominant heating during boreal summer (June, July, August) from the twentieth to the twenty-first century? Figure 3 illustrates differences in heat sources and sinks between the last half of the twenty-first (2050-2099) and the twentieth century (1950-1999). Increased sensible heating is seen mainly over western and central continents (North America, Africa and western Eurasia); condensational heating over the East Asian

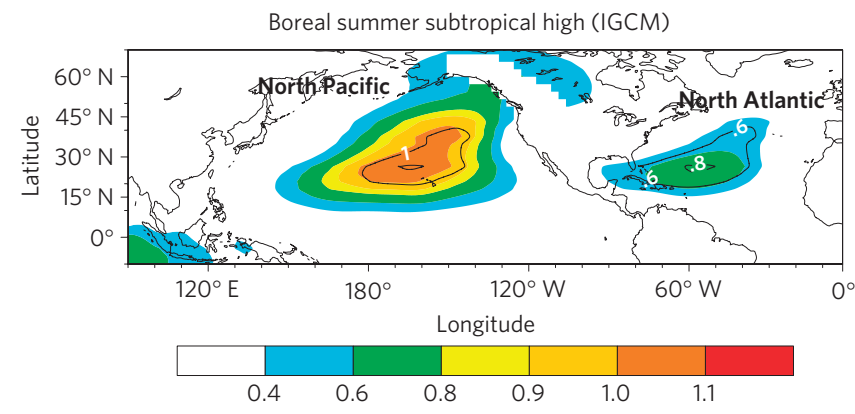

Figure 5 | Idealized GCM simulation. The modelled $925 \mathrm{hPa}$ zonally asymmetric component of the stream function of the summertime subtropical highs in the Northern Hemisphere with the forced diabatic heating changes (contour) compared with that of the boreal summer basic-state climatology (shaded) using the idealized GCM (unit: $10^{7} \mathrm{~m}^{2} \mathrm{~s}^{-2}$ ). Forced heating fields are obtained from the difference in atmospheric diabatic heating between the twentieth century (1950-1999) and the twenty-first century (2050-2099).

monsoon region and western subtropical Pacific; and enhanced long-wave radiative cooling over the eastern Atlantic and eastern Pacific. This is also confirmed by the vertical profiles of diabatic heating changes (Fig. 4). Figure 4 shows that total diabatic heating is predicted to increase in the lower troposphere over the western continents, with the maximum change near the surface. Such enhanced heating decreases with altitude in the lower troposphere, indicating that total diabatic heating change is dominated by sensible heating change over western continents (Fig. 4, red curves). Similarly, increased diabatic heating maximizes in the middle to upper troposphere over eastern continents, suggesting the dominant diabatic heating component to be condensational heating over these regions (Fig. 4, green curves). Over the eastern oceans, changes of total diabatic heating are dominated by long-wave radiative cooling associated with marine stratus clouds (Fig. 4, blue curves). The vertical structures of the diabatic heating changes (Fig. 4) are similar to that of the heating climatology ${ }^{31}$, indicating enhanced land-sea thermal contrasts in a warming climate.

Why does enhanced land-sea thermal contrast lead to intensification of the subtropical anticyclones? One possible explanation is through atmospheric responses to a strong cooling (heating) over oceans (lands) by the generation of anticyclonic (cyclonic) circulation anomalies as suggested previously ${ }^{32,33,35}$. Thus, the enhancement of diabatic heating over continents and cooling over oceans in the twenty-first century favours a stronger near-surface anticyclonic circulation over oceans in the lower troposphere.

To further illustrate the relationship between changes in diabatic heating and the changes in subtropical high intensity, we perform sensitivity experiments with an idealized general circulation model (GCM) as done previously ${ }^{36,37}$ to study the impact of the changes in diabatic heating from the twentieth century (1950-1999) to the twenty first century (2050-2099) on the intensification of the Northern Hemisphere subtropical highs. The summer basic-state climatology of the ECMWF (1979-1993) is maintained in the idealized GCM through the restoration terms ${ }^{37}$. The changes in diabatic heating obtained from the CMIP3 multi-model ensemble results are then added to the idealized GCM. The resulting stream function field is plotted in Fig. 5 in contours and the basic-state climatology is shown in shading. Figure 5 indicates an intensification of the North Pacific Subtropical High response to the diabatic heating change. Specifically, the local maximum stream function increases from $1.0 \times 10^{7} \mathrm{~m}^{2} \mathrm{~s}^{-2}$ to $1.1 \times 10^{7} \mathrm{~m}^{2} \mathrm{~s}^{-2}$, and the area of the high's centre greater than $1.0 \times 10^{7} \mathrm{~m}^{2} \mathrm{~s}^{-2}$ expands by about $20 \%$. Similarly to the North Pacific Subtropical High, the centre 
intensity of the North Atlantic Subtropical High increases from $0.6 \times 10^{7} \mathrm{~m}^{2} \mathrm{~s}^{-2}$ to $0.8 \times 10^{7} \mathrm{~m}^{2} \mathrm{~s}^{-2}$ with a more westward and northeastward expansion when forced diabatic heating is added (Fig. 5). Idealized GCM experiments further confirm that the near-surface anticyclonic circulations over the North Atlantic and North Pacific owe their enhancement largely to the stronger diabatic heatings over land and radiative cooling over oceans during summer in a warming climate.

Using the ERA-40 reanalysis, the CMIP3 models' output and idealized GCM simulations, this study shows strengthening of the near-surface summertime subtropical highs over the North Pacific and North Atlantic in the future climate with an increase of GHGs. The results suggest that the intensification of the highs may lead to substantial changes in weather and climate patterns on regional, continental and hemispheric scales ${ }^{7,17}$.

\section{Methods}

The data used in this study consist of the atmospheric circulation field from the ECMWF ERA-40 (ref. 23) from 1958 to 2002 at http://data-portal.ecmwf.int/data/d/era40_moda/, and from the coupled oceanatmospheric GCMs for the IPCC AR4 that are available at the Program for Climate Model Diagnosis and Intercomparison at https://esg.llnl.gov:8443/index.jsp. The stream function is obtained by solving Poisson's equation. We considered three sets of simulations: pre-industrial runs (PICNTRL), twentieth-century-forced runs $(20 \mathrm{C} 3 \mathrm{M})$ and the twenty-first-century simulations under the emission scenario A1B (A1B). The PICNTRL experiments represent the natural variability of a coupled ocean and atmosphere climate system with GHGs fixed at the pre-industrial level. The forced experiments for the twentieth century (20C3M) are driven by estimated changes in a variety of anthropogenic forcings and, for some models, the changes in natural external forcings such as solar irradiance variation and volcanic aerosols. The A1B scenario describes a future world of very rapid economic growth and global population that peaks in mid-century and declines thereafter and describes the rapid introduction of new and more efficient technologies ${ }^{25}$. In the twenty-first century simulations, the $\mathrm{CO}_{2}$ concentration doubles to $720 \mathrm{ppm}$ in 2100 , after which it is fixed. There are 23 models in the pre-industrial controlled run, the twentieth-century-forced runs and the twenty-first-century simulations.

Following previous studies $5,38,39$, the $925 \mathrm{hPa}$ stream function was chosen to characterize the near-surface summer subtropical anticyclonic circulations in this study. Summer seasonal means are obtained by taking an average over the months of June, July and August in the Northern Hemisphere.

The three-dimensional atmospheric diabatic heating rate is calculated as a residual from the thermodynamic energy equation ${ }^{40-42}$ using monthly data, and then averaged over June, July and August in the Northern Hemisphere for the CMIP3 models' output. The total column heating is obtained for the whole atmosphere described in the Supplementary Information.

\section{Received 20 March 2012; accepted 24 August 2012; published online 30 September 2012}

\section{References}

1. Rodwell, M. J. \& Hoskins, B. J. Subtropical anticyclones and summer monsoon. J. Clim. 14, 3192-3211 (2001).

2. Wu, G. et al. Multi-scale forcing and the formation of subtropical desert and monsoon. Ann. Geophys.-Germany 27, 3631-3644 (2009).

3. Miyasaka, T. \& Nakamura, H. Structure and mechanisms of the Southern Hemisphere summertime subtropical anticyclones. J. Clim. 23, 2115-2130 (2010).

4. Davis, R. E., Hayden, B. P., Gay, D. A., Phillips, W. L. \& Jones, G. V. The North Atlantic Subtropical anticyclone. J. Clim. 10, 728-744 (1997).

5. Lu, R. \& Dong, B. Westward extension of North Pacific subtropical high in summer. J. Meteorol. Soc. Jpn 79, 1229-1241 (2001).

6. Gamble, D. W., Parnell, D. B. \& Curtis, S. Spatial variability of the Caribbean mid-summer drought and relation to north Atlantic high circulation. Int. J. Climatol. 28, 343-350 (2008).

7. Li, W., Li, L., Fu, R., Deng, Y. \& Wang, H. Changes to the North Atlantic subtropical high and its role in the intensification of summer rainfall variability in the Southeastern United States. J. Clim. 24, 1499-1506 (2011).

8. Zhou, T. \& Yu, R. Atmospheric water vapor transport associated with typical anomalous summer rainfall patterns in China. J. Geophys. Res. 110, D08104 (2005).

9. Koicha, K. Climatological study on the relationship between the Japanese summer weather and the subtropical high in the western North Pacific. Geophyl. Mag. 43, 45-104 (1989).

10. Sun, S. \& Ying, M. Subtropical high anomalies over the western pacific and its relations to the Asian monsoon and SST anomaly. Adv. Atmos. Sci. 16, 559-568 (1999).
11. Kasahara, A. A comparison between geostrophic and non-geostrophic numerical forecasts of hurricane movement with the barotropic steering model. J. Meteorol. 16, 371-384 (1959).

12. Stowasser, M., Wang, Y. \& Hamilton, K. Tropical cyclone changes in the Western North Pacific in a global warming scenario. J. Clim. 20, 2378-2396 (2007).

13. Wu, L., Wang, B. \& Geng, S. Growing typhoon influence on east Asia. Geophys. Res. Lett. 32, L18703 (2005).

14. Klein, S. A. \& Hartmann, D. L. The seasonal cycle of low stratiform clouds. J. Clim. 6, 1587-1606 (1993).

15. Klein, S. A., Hartmann, D. L. \& Norris, J. R. On the relationships among low-cloud structure, sea-surface temperature, and atmospheric circulation in the summertime Northeast Pacific. J. Clim. 8, 1140-1155 (1995).

16. Sui, C-H., Chung, P-H. \& Li, T. Interannual and interdecadal variability of the summertime western North Pacific subtropica high. Geophys. Res. Lett. 34, L11701 (2007).

17. Zhou, T. et al. Why the Western Pacific subtropical high has extended westward since the Late 1970s. J. Clim. 22, 2199-2215 (2009).

18. Wu, B. \& Zhou, T. Oceanic origin of the interannual and interdecadal variability of the summertime western Pacific subtropical high. Geophys. Res. Lett. 35, L13701 (2008).

19. Seager, R., Naik, N. \& Vecchi, G. A. Thermodynamic and dynamic mechanisms for large-scale changes in the hydrological cycle in response to global warming. J. Clim. 23, 4651-4668 (2010).

20. Henderson, K. G. \& Vega, A. J. Regional precipitation variability in the southeastern United States. Phys. Geogr. 17, 93-112 (1996).

21. Katz, R. W., Parlange, M. B. \& Tebaldi, C. Stochastic modeling of the effects of large-scale circulation on daily weather in the southeastern US. Climatic Change 60, 189-216 (2003).

22. Stahle, W. D. \& Cleaveland, M. K. Reconstruction and analysis of spring rainfall over the Southeastern U.S for the past 1000 years. Bull. Am. Meteorol. Soc. 73, 1947-1961 (1992).

23. Uppala, S. M. et al. The ERA-40 re-analysis. Q. J. R. Meteorol. Soc. 131, 2961-3012 (2005)

24. Meehl, G. A. et al. The WCRP CMIP3 multi-model dataset: A new era in climate change research. Bull. Am. Meteorol. Soc. 88, 1383-1394 (2007).

25. Nakicenovic, N. et al. IPCC Special Report on Emissions Scenarios (Cambridge Univ. Press, 2000).

26. Grotjahn, R. Global Atmospheric Circulations: Observations and Theories (Oxford Univ. Press, 1993).

27. Grotjahn, R. \& Osman, M. Remote weather associated with North Pacific subtropical sea-level high properties. Int. J. Climatol. 27, 587-602 (2007).

28. Hoskins, B. J. On the existence and intensity of summer subtropical anticyclones. Bull. Am. Meteorol. Soc. 77, 1287-1291 (1996).

29. Chen, P., Hoerling, M. P. \& Dole, R. M. The origin of the subtropical anticyclones. J. Atmos. Sci. 58, 1827-1835 (2001).

30. Ting, M. Maintenance of northern summer stationary waves in a GCM. J. Atmos. Sci. 51, 3268-3308 (1994).

31. Wu, G. \& Liu, Y. Summertime quadruplet heating pattern in the subtropics and the associated atmospheric circulation. Geophys. Res. Lett. 30, 1201 (2003).

32. Hoskins, B. J. Towards a PV- $\theta$ view of the general circulation. Tellus. Ser. AB 43, 27-35 (1991).

33. Wu, G. \& Liu, Y. Thermal Adaptation, overshooting, dispersion, and subtropical anticyclone Part I: Thermal adaptation and overshooting. Chin. J. Atmos. Sci. 24, 433-446 (2000).

34. Liu, Y., Wu, G. \& Ren, R. Relationship between the subtropical anticyclone and diabatic heating. J. Clim. 17, 682-698 (2004).

35. Miyasaka, T. \& Nakamura, H. Structure and formation mechanisms of the Northern hemisphere summertime subtropical highs. J. Clim. 18, 5046-5065 (2005)

36. Hoskins, B. J. \& Rodwell, M. J. A model of the Asian summer monsoon, Part I: The global scale. J. Atmos. Sci. 52, 1329-1340 (1995).

37. Liu, Y., Hoskins, B. J. \& Blackburn, M. Impacts of the Tibetan topography and heating on the summer flow over Asia. J. Meteorol. Soc. Jpn 85B, 1-19 (2007).

38. Lu, R. Indices of the summertime western North Pacific subtropical high. Adv. Atmos. Sci. 19, 1004-1028 (2002).

39. Park, J-Y., Jhun, J-G., Yim, S-Y. \& Kim, W-M. Decadal changes in two types of the western North Pacific subtropical high in boreal summer associated with Asian summer monsoon/El Niño-Southern Oscillation connections. J. Geophys. Res. 115, D21129 (2010).

40. Chan, S. C. \& Nigam, S. Residual diagnosis of diabatic heating from ERA-40 and NCEP reanalyses: Intercomparisons with TRMM. J. Clim. 22, 414-428 (2009)

41. Hoskins, B. J. et al. Diagnostics of the global atmospheric circulation. Based on ECMWF analysis 1979-1989. Department of Meteorology, University of Reading, Compiled as part of the UK Universities Global Atmospheric Modelling Project, WMO/TD-NO. 326 (1989). 
42. Nigam, S. On the dynamical basis for the Asian summer monsoon rainfall-El Nino relationship. J. Clim. 7, 1750-1771 (1994).

\section{Acknowledgements}

We thank the international modelling groups for providing their data for analysis, the Program for Climate Model Diagnosis and Intercomparison for collecting and archiving the model data, the ISC/CLIVAR Working Group on Coupled Modelling and their Coupled Model Intercomparison Project and Climate Simulation Panel for organizing the model data analysis activity, and the IPCC WG1 TSU for technical support. The IPCC Data Archive at Lawrence Livermore National Laboratory is supported by the Office of Science, US Department of Energy. We sincerely thank G. Wu, F. Jin and P. A. Baker for helpful discussions, P. Zhang and C. Li for graphics help, and H. M. Aird and I. Stuart for editorial assistance. This work is supported by the NSF AGS 1147608, and Y. Liu is supported by NSFC 40925015.

\section{Author contributions}

W.L. led the study and wrote the manuscript; L.L. carried out data analyses, prepared Figs 1-4 and documented the study. Y.L. conducted the idealized GCM simulation and prepared Fig. 5, M.T. participated in science discussion. All authors contributed to the data and model interpretation and revisions.

\section{Additional information}

Supplementary information is available in the online version of the paper. Reprints and permissions information is available online at www.nature.com/reprints. Correspondence and requests for materials should be addressed to W.L.

\section{Competing financial interests}

The authors declare no competing financial interests. 